\title{
Building a High-Quality Science Teaching: Views of Basic School Science Teachers in Akuapem South District of the Eastern Region, Ghana
}

\author{
Adjibolosoo, Saviour Victor Kwabla ${ }^{1 *} \quad$ Bentil, Joseph Rockson $^{2} \quad$ Nanor, Jacob Nene ${ }^{1}$ \\ Baah-Yanney, Obed ${ }^{1}$ \\ 1.Department of Science, Presbyterian Women's College of Education, Ghana \\ 2.Department of Science, Komenda College of Education, Ghana
}

\begin{abstract}
Quality education for all is one of the most powerful and proven vehicles for achieving the Sustainable Development Goals. However, Science teachers encounter considerable challenges when teaching science at the basic school level. Objective: This paper investigated teachers' knowledge of science-based global best practices and the challenges hindering them from teaching science effectively. Methodology: The study was a school-based cross-sectional survey which employed quantitative research approach and descriptive research design. Data for the study was obtained by administering a five-point Likert scale type structured questionnaires to 257 science teachers randomly selected across the basic schools within the Akuapem South District of the Eastern Region. Data analysis: Descriptive statistics, Chi-square test, and Student's t-test were applied to the data to establish the knowledge level of teachers on science specific global best practices and ascertain if there are significant differences in challenges science teachers face in the course of their effort to create conducive learning environment for children to develop science core competencies, concepts and skills. Results: The results of the study showed that teachers had adequate knowledge of science-based global best practices. However, lack of teaching and learning resources and over-reliance on improvised teaching learning materials were perceived among the greater number of teachers as the most important drawback to effective teaching and learning of science in the district. Also, the basic electronics was found to be the single most important concept science teachers found very difficult in teaching. Conclusion: These findings provide a holistic understanding of the teachers' knowledge of science-based global best practices and the challenges they face in teaching science at the basic school level. Recommendations: To enhance effective teaching and learning of science at the basic school level, the Ghana Education Service must support science teachers with relevant teaching learning resources, and Akuapem South Education District must organise refresher courses and workshops for science teachers to upgrade their knowledge on both contents and pedagogical content knowledge necessary for teaching and learning of basic electronic concept in the basic school curriculum.
\end{abstract}

Keywords: High-Quality Science Teaching, Basic Schools, Science Teachers Challenges, Akuapem South District, Eastern Region, Ghana.

DOI: $10.7176 / \mathrm{JEP} / 11-3-10$

Publication date: January $31^{\text {st }} 2020$

\section{Introduction}

Quality education for all is one of the most powerful and proven vehicles for achieving the Sustainable Development Goals. The role of science education in achieving these goals cannot be underestimated. Science education at the basic school level is carried out to develop children's attitudes and provide them with basic knowledge and skills that are essential for survival in the $21^{\text {st }}$ century contemporary society. Science teachers are therefore being challenged to transform educational outcomes, often under difficult conditions. They are being asked to equip students with the competencies (knowledge, values, skills, attitudes) they need to become active citizens and workers in the 21 st century. Therefore effective Science education which is relevant for sustainable development should be inquiry-based and learner centered. Pedaste et al., (2012), defined inquirybased learning as a process of discovering new causal relations, with the learner formulating hypotheses and testing them by conducting experiments and/or making observations. Thus engaging learners physically and cognitively in the knowledge, skills, attitudes and value-acquiring process about the world, in a rich and rigorous inquirydriven environment is critical in effective teaching and learning of science. Science teachers serve as facilitators by providing and designing the enabling environment that promotes critical thinking, creativity, collaboration and construction of learners' own knowledge based on their previous experiences.

However, basic school science teaching has been found to be associated with numerous challenges of greater accountability. Thus science educators at this level often express grave distress and anxiety when finding ways and means to address the challenges. These challenges manifested in different ways such as when trying to understand the curriculum content and goals; knowledge of learners; and pedagogical content knowledge. Others occur when preparing lesson plans; designing and planning learner-centered activities; developing analogies; and 
selecting appropriate teaching learning resources to aid students' learning through critical thinking, collaboration and creativity; answering students' questions; linking and applying various concepts and principles to everyday life situations; generating students' interest and passion for the Science. The objective of teaching Science is to provide a children-centered learning environment that meets the needs of individual students with diverse sociocultural background.

Quality education for all is one of the most powerful and proven vehicles for achieving the Sustainable Development Goals. However, science teachers encounter considerable challenges when teaching science at the basic school level. Academic literature reviewed indicated no empirical study has investigated the teachers' knowledge of science-based global best practices and the challenges hindering them from effective teaching of science at the basic school level. This paper investigates teachers' knowledge of science-based global best practices and the challenges hindering them from teaching science effectively at the basic schools.

\section{Literature Review}

The academic literature reviewed in this study focuses on two main areas: teachers' knowledge of science-based global best practices and the challenges of teaching science at basic schools level.

\section{Teachers' Knowledge of Science-Based Global Best Practices}

It is imperative that science teachers consistently and continuously keep up-to-date with new knowledge, skills and teaching. They need to understand the structure and nature of the discipline and learn unfamiliar content knowledge, which is known as subject matter knowledge. They need to transform the content knowledge into suitable activities, analogies, demonstrations or simulations and adapt them to the different students' abilities to help them learn, what is described by Shulman (1986) as pedagogical content knowledge. One of the sciencebased global best practices is that science teachers must serve as facilitators by providing and designing the enabling environment that promotes critical thinking, creativity, collaboration and construction of learners' own knowledge based on their previous experiences. Studies show that teachers' inadequate background knowledge of the subject matter is one of the main factors that contributes to the challenges they encounter and this have an impact on the development of their pedagogical content knowledge as well as on the teachers' self-confidence and attitudes when teaching concepts in Science. The teachers' knowledge base strongly influences all aspects of teaching like preparation, planning and decision making regarding the choice of content to be learnt (De Jong, Veal, \& Van Driel, 2002). Therefore, one can argue that one of the most important characteristics of being a good science teacher is having a very good basis of subject matter knowledge.

However, research studies which have attempted to find a relationship between subject matter knowledge and good teaching (Abell, 2007; Childs \& Mc Nicholl, 2007; Hashweh, 1987; Kind, 2009) suggest that while a good background in subject matter knowledge is a pre-requisite for good teaching, it is not the only requirement. Exemplary science teachers, as argued by Shulman $(1986,1987)$ also need to develop pedagogical content knowledge which enables science teachers to blend content and pedagogy into an understanding of how particular topics, problems, or issues are organised, represented, and adapted to the diverse interests and abilities of learners and presented for instruction (Shulman, 1987). Magnusson et al. (1999) describe pedagogical content knowledge for science teaching as the transformation of several types of knowledge not only subject matter knowledge. These knowledge areas consist of five components which include orientation toward science teaching, knowledge and beliefs about the science curriculum and assessment in science, knowledge about students' understanding and misconceptions of specific science topics and knowledge about instructional strategies for teaching science or topic specific pedagogy.

Pedagogical content knowledge develops with teachers' experience (Abell, 2008; Davis et al., 2007). It is a cyclical process whereby teachers transform, reflect and evaluate their practices and continue to learn as they develop their practices. Pedagogical content knowledge is also content-specific or subject-specific knowledge that is fundamental for effective science teaching (Magnusson et al., 1999). Subject-specific knowledge entails general strategies applicable to teach science. Content-specific strategies, such as illustrations, models, analogies, experiments and activities are required when teaching particular topics within a science field. This implies that teachers need to develop different instructional strategies when teaching science. Displaying an in-depth knowledge of the subject matter and global best practices help teachers provide different approaches and alternative descriptions to help students understand intricate scientific concepts and principles. Under the global best practices, the quality of the science teachers goes beyond their being mere communicators of content, and encompass their roles as leaders in pedagogical thinking, inspirational role models, respected domain experts and custodians of societal values teaching (Magnusson et al., 1999).

A 2010 report on review of teacher education in Scotland highlighted the following qualities and skills of twenty-first century teachers:

"Reflectiveness; commitment to teaching as a vocation and the development and learning of each child; passion for learning and deep understanding of and enthusiasm for the subject-matter; 
willingness to share ideas and network with colleagues; and keenness to participate in personal learning and development" (Donaldson, 2010; p.12).

This suggests that a twenty-first century science teacher in a rapidly changing world must be a lifelong practitioner, be cognizant of the changing nature of knowledge, learning, and learning environments; and embrace new pedagogies and transform pedagogical practices including problem solving, critical thinking, collaboration, creativity, and interpersonal skills into the learning situations.

\section{Challenges of Teaching Science in Basic Schools}

A study that Al Shammeri (2013) conducted to explore the views of 136 science teachers who are teaching a reformed science curriculum in Kuwait revealed that these teachers face a number of challenges like the difficulty of the content, heavy workload, lack of teaching tools, inadequate professional development, not enough time allocated to teach science and class management issues because of large class sizes.

Another study that investigated the challenges facing primary science teachers in Turkey (Sengul, Cetin \&Gur, 2008) identified a number of problems such as lack of pedagogical knowledge, lack of physical resources and time constraints. Al Ghamdi and Al Salouli (2013) interviewed science teachers in public and private schools in Al Dammam in the Kingdom of Saudia Arabia and the findings of their study suggest that insufficient instructional time, limited physical space, scarcity of resources, and professional development are barriers that hinder the implementation of the reformed science curricula. Based on this, it is necessary to have an atmosphere of learning that is in accordance with the stage of thinking of students. If learning is not in accordance with the stage of thinking of students, learning becomes meaningless. Based on this, the learning process must require students to be actively involved in learning. In the implementation of learning in elementary schools, learning must emphasize the $21^{\text {st }}$ century modern pedagogical dimension and prioritize personal experience through the scientific process. Daryanto (2014) suggests that the scientific learning process is designed so that students actively construct concepts, laws and principles. The stages of the scientific process are observing, formulating problems, proposing hypotheses, collecting data, analyzing data, drawing conclusions, and ending by communicating the concepts that have been cofound. Based on this, learning must be linked to the environment and the lives of students on a daily basis. Students must interact directly with what they learn in order to understand the material. Interacting directly can provide a good learning experience for students. In addition, students can also explore information in depth. As revealed by Samatowa (2011) that direct experience provides an important role as a driving force for children's cognitive development, and learning models suitable for basic school children are learning through direct experience. Basic school science teachers therefore need to personalize learning experiences to ensure that every child has a chance to succeed and to deal with increasing cultural diversity in their classrooms and differences in learning styles. They also need to keep up with innovations in curricula, pedagogy and the development of digital resources. In many high-performing education systems science teachers therefore have a central role to play in improving educational outcomes.

\section{Materials and Methods}

The study was school-based cross-sectional survey which sought to investigate the teachers' knowledge of sciencebased global best practices and the challenges hindering them from teaching science effectively. The method that was used in this research was a school-based cross-sectional survey and the design was descriptive. The sample frame was basic school science teachers in Akuapem South District of the Eastern Region. The sample population was selected using random sampling procedures. The study employed questionnaires to collect self-reported data from 257 basic school science teachers who have been teaching science in the basic schools for at least three years. Study (Dillman et al., 2008) has shown that people who are asked directly for self-reported data provide more positive feedback than when asked through an anonymous web survey. The mean age of the sample population was 2.59. Female made up 52.1\% of the sample. We obtained approval from the Akuapem South District Education Directorate prior to collecting any data.

Sixteen constructs measures on the questionnaire guide were used to assess the teachers' knowledge of perceived science-based global best practices and thirteen constructs measures on the questionnaire guide were used to assess the perceived challenges teachers face in teaching science effectively. The teachers' knowledge of perceived science-based global best practices and the perceived challenges teachers face in teaching science effectively were measured on a 5-point Likert scale ranging from 1 (strongly disagree) to 5 (strongly agree) based on Oliver's (1997) study. Finally, the teachers were asked to respond to three descriptive questions including sex, age, and academic qualification.

The instrument was first piloted with 20 science teachers in non-selected district to test its reliability and validity. The research team finally applied item judgment to maximize the questionnaire validation — clarity, readability and content validity of items. This was followed by administration of the questionnaire to 257 randomly selected science teachers. The questionnaire administration was conducted by the research team supported by personnel from the district education office within the period of three weeks spanning from $8^{\text {th }}$ June $-29^{\text {th }}$ June 
2019. Quality control measures such as the need for independent completion of the questionnaires and freedom of participation or withdrawal from the study were strictly followed. Special efforts were also made to minimize methodological, personal and social desirability biases.

\section{Data Analysis}

Data analysis was done using SPSS 21.0 Statistical Package Program. Statistical tests used in data analysis were chi-square test, a t-test and descriptive statistics. Test items reliability and internal consistency were determined using Cronbach's alpha statistics (Cronbach, \& Richard, 2004). The calculated values were greater than 0.8 indicating that items on the instruments have sufficient internal consistency (Pallant, 2011; Cronbach \& Richard, 2004). Descriptive statistics was used to determine the frequency and percentage distribution of teachers' demographic characteristics. In these tests, score 0.05 was used as significance level. If the showed less than 0.05 , it was accepted. If the showed more than 0.05 , it was rejected.

\section{Results}

This section describes all the results of data analyses, including teachers' demographics, basic descriptive results, reliability of all measurement items, and the validity of the measurement structure. Respondents' demographic characteristics are summarized in Table 1.

\section{Table 1: Characteristics of Science Teachers}

\begin{tabular}{|c|c|c|c|}
\hline Demographics & Frequency/Percentage & Mean & Standards Deviation \\
\hline \multicolumn{4}{|l|}{ Sex } \\
\hline Males & $123(47.9)$ & & \\
\hline Females & $134(52.1$ & 1.53311 & .52280 \\
\hline \multicolumn{4}{|l|}{ Age Distribution } \\
\hline $20-25$ & $40(14.8)$ & \multirow{5}{*}{2.5875} & \multirow{5}{*}{1.15967} \\
\hline $26-31$ & $107(39.6)$ & & \\
\hline $32-37$ & $49(18.1)$ & & \\
\hline $38-42$ & $41(15.2)$ & & \\
\hline Above 42 & $20(7.4)$ & & \\
\hline \multicolumn{4}{|l|}{ Qualification } \\
\hline Cert A 4-Year & $4(1.6)$ & \multirow{6}{*}{3.2101} & \multirow{6}{*}{.66337} \\
\hline Cert A 3-Year & $20(7.8)$ & & \\
\hline Diploma & $154(59.9)$ & & \\
\hline B.ED Degree & $76(29.6)$ & & \\
\hline Master's Degree & $3(1.2)$ & & \\
\hline Total & $257(100)$ & & \\
\hline
\end{tabular}


Table 2: Descriptive Statistics Results Table of Teachers' Knowledge of Science-Based Global Best Practices

\begin{tabular}{|c|c|c|c|}
\hline Constructs & Mean & $\begin{array}{c}\text { Std. } \\
\text { Deviation }\end{array}$ & $\begin{array}{l}\text { Std. Error } \\
\text { Mean }\end{array}$ \\
\hline - $\quad$ Teachers need to be life-long learners. & 4.3619 & .89125 & .05559 \\
\hline $\begin{array}{l}\text { - Relating classroom lessons to real life situations is relevant in science } \\
\text { teaching and learning. }\end{array}$ & 3.7471 & 1.41775 & .08844 \\
\hline - Not every science topic has relevant previous knowledge. & 2.5214 & 1.36378 & .08507 \\
\hline $\begin{array}{l}\text { - Pupils understand science concepts better when it is explained using } \\
\text { the local language. }\end{array}$ & 3.3385 & 1.50461 & .09386 \\
\hline $\begin{array}{l}\text { - Pupils' interest in science lessons can be stimulated through } \\
\text { punishment. }\end{array}$ & 2.0428 & 1.17681 & .07341 \\
\hline - Not every science topics requires use of teaching learning materials. & 2.0584 & 1.22494 & .07641 \\
\hline $\begin{array}{l}\text { - Weekly lesson plans do not encourage the use of reflective feedback in } \\
\text { subsequent lessons. }\end{array}$ & 2.5447 & 1.39157 & .08680 \\
\hline $\begin{array}{l}\text { - Remarks in science lessons cover only pupils' level of understanding } \\
\text { and not teacher's methodology. }\end{array}$ & 2.6148 & 1.42640 & .08898 \\
\hline $\begin{array}{l}\text { - During science lessons, the teacher must strictly follows what he/she } \\
\text { has planned to teach. }\end{array}$ & 2.5914 & 1.43356 & .08942 \\
\hline $\begin{array}{l}\text { - Ability to create opportunities for pupils to think critically and solve } \\
\text { problems is an important characteristic of a science teacher. }\end{array}$ & 3.6342 & 1.44916 & .09040 \\
\hline $\begin{array}{l}\text { - Introduction to every science lessons requires use of relevant previous } \\
\text { knowledge. }\end{array}$ & 3.6187 & 1.38720 & .08653 \\
\hline $\begin{array}{l}\text { - Teachers must share their lesson objective(s) with pupils any time they } \\
\text { are about to teach. }\end{array}$ & 3.6342 & 1.36017 & .08485 \\
\hline $\begin{array}{l}\text { - Pupils' misconceptions are relevant resources in science teaching and } \\
\text { learning. }\end{array}$ & 3.2646 & 1.45775 & .09093 \\
\hline $\begin{array}{l}\text { - In preparing science lesson plan, any one of the three main curriculum } \\
\text { materials provides adequate information. }\end{array}$ & 3.0506 & 1.42020 & .08859 \\
\hline $\begin{array}{l}\text { - Lesson introduction helps eliminate pupils' misconceptions in the } \\
\text { previous knowledge. }\end{array}$ & 3.0195 & 1.50117 & .09364 \\
\hline $\begin{array}{l}\text { - Teaching and learning is a collaborative work between the teacher and } \\
\text { the learners. }\end{array}$ & 3.8560 & 1.42477 & .08887 \\
\hline $\begin{array}{l}\text { RANKING OF MEAN VALUES: } \\
\text { 3.0-3.9 (good knowledge); 2.0-2.9 }\end{array}$ & & & \\
\hline
\end{tabular}

Fig 1: Bar graph of Topics Science Teachers Find Difficult in Teaching

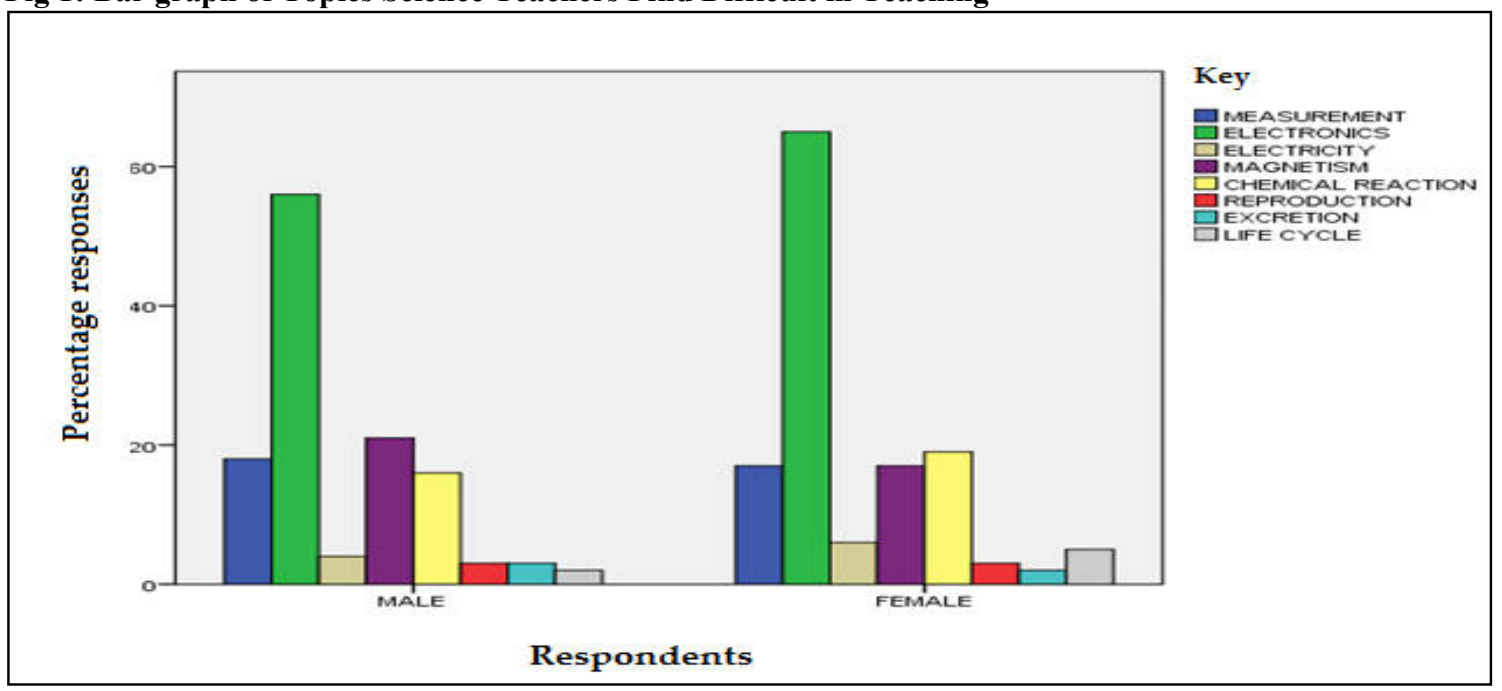

$[\chi=13.674, \mathrm{p}<0.05]$ 
Table 3: Descriptive Statistics Results Table of Challenges Science Teachers Face during Science Teaching

\begin{tabular}{|c|c|c|c|}
\hline Constructs & Mean & $\begin{array}{c}\text { Std. } \\
\text { Deviation }\end{array}$ & $\begin{array}{c}\text { Std. Error } \\
\text { Mean }\end{array}$ \\
\hline - Helping learners to apply what they learn in class is a challenging task. & 3.1089 & 1.51161 & .09429 \\
\hline - Keeping record on individual pupil is a challenging task. & 2.7977 & 1.48886 & .09287 \\
\hline $\begin{array}{l}\text { - Establishing learning environment for pupils for skill development is a } \\
\text { challenging task. }\end{array}$ & 2.8638 & 1.46340 & .09128 \\
\hline $\begin{array}{l}\text { - Individualizing teaching and learning activities in the classroom is a } \\
\text { challenging task }\end{array}$ & 3.0584 & 1.54632 & .09646 \\
\hline $\begin{array}{l}\text { - Focusing pupils' attention to key issues during science lessons is a } \\
\text { challenging task. }\end{array}$ & 2.7198 & 1.47085 & .09175 \\
\hline $\begin{array}{l}\text { - Getting relevant teaching-learning materials for teaching science is a } \\
\text { challenging task. }\end{array}$ & 3.5564 & 1.48091 & .09238 \\
\hline $\begin{array}{l}\text { - Getting materials to prepare teaching- learning aids for science lessons } \\
\text { is very challenging. }\end{array}$ & 3.7743 & 1.22301 & .07629 \\
\hline - Pupils do not show interest in science lesson in my class. & 2.4514 & 1.37733 & .08592 \\
\hline $\begin{array}{l}\text { - It is difficult completing a scheme of work prepared for science in a } \\
\text { term }\end{array}$ & 2.8599 & 1.44827 & .09034 \\
\hline - I use improvised TLMs for science lessons than real TLMs. & 3.3268 & 1.62084 & .10111 \\
\hline $\begin{array}{l}\text { - Addressing pupils' misconceptions during science lessons is very } \\
\text { challenge. }\end{array}$ & 2.6809 & 1.41122 & .08803 \\
\hline $\begin{array}{l}\text { - Weekly lesson plan makes it difficult for teachers to build on previous } \\
\text { successes and correct the weaknesses in subsequent lessons. }\end{array}$ & 2.9689 & 1.53061 & .09548 \\
\hline $\begin{array}{l}\text { - Write down any TWO topics in science that you find difficult in } \\
\text { teaching. }\end{array}$ & 2.9611 & 1.70890 & .10660 \\
\hline
\end{tabular}

Fig 1: Bar graph of Topics Science Teachers Find Difficult in Teaching

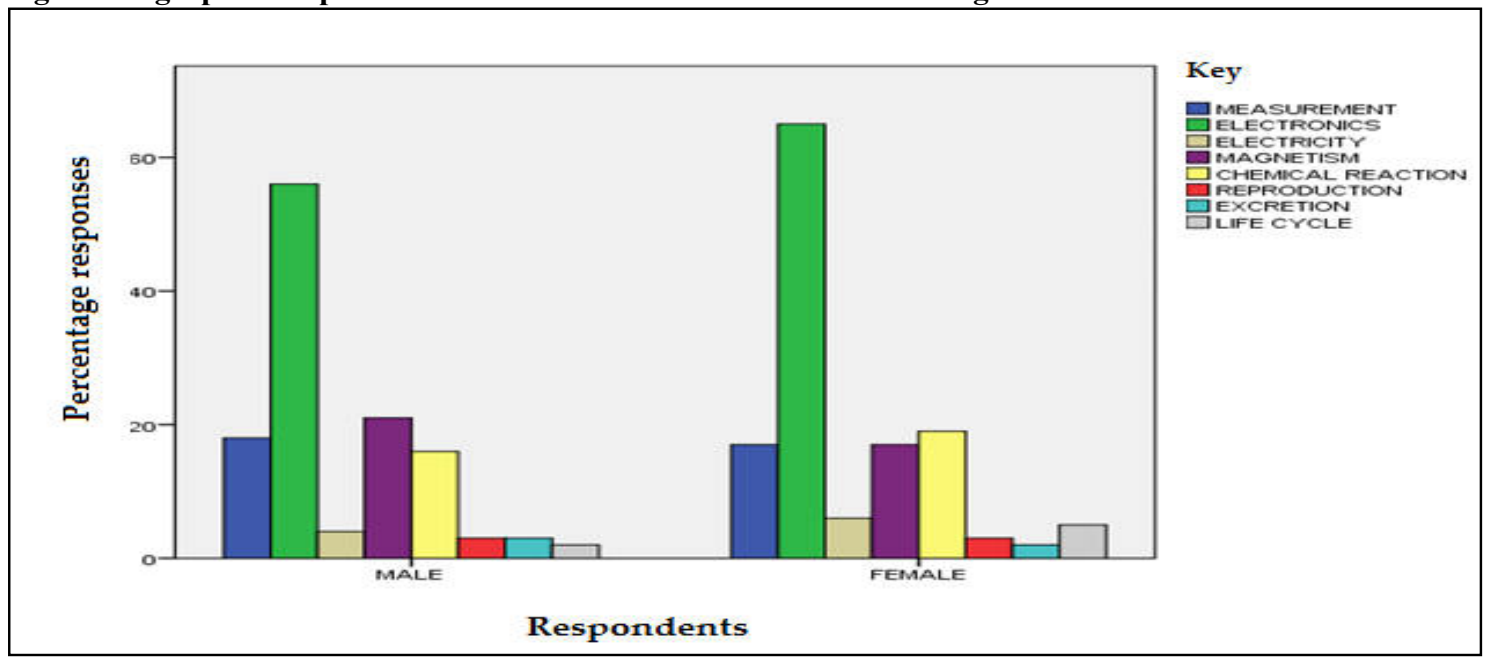

$[\chi=13.674, \mathrm{p}<0.05]$ 
Table 4: T-Statistics Results of Challenges Science Teachers Face during Science Teaching

\begin{tabular}{|c|c|c|c|c|c|}
\hline \multirow[t]{3}{*}{ Challenges Faced During Science Teaching } & \multicolumn{5}{|c|}{ One-Sample Test: $\mathrm{N}=\mathbf{2 5 7}, \mathrm{df}=\mathbf{5 6}$} \\
\hline & \multirow[t]{2}{*}{$\mathrm{t}$} & \multirow[t]{2}{*}{$\begin{array}{c}\mathrm{p}- \\
\text { value }\end{array}$} & \multirow[t]{2}{*}{$\begin{array}{c}\text { Mean } \\
\text { Difference }\end{array}$} & \multicolumn{2}{|c|}{$\begin{array}{l}95 \% \text { Confidence } \\
\text { Interval of the } \\
\text { Difference }\end{array}$} \\
\hline & & & & Lower & Upper \\
\hline $\begin{array}{l}\text { Helping learners to apply what they learn in } \\
\text { class is a challenging task. }\end{array}$ & 32.972 & .000 & 3.10895 & 2.9233 & 3.2946 \\
\hline $\begin{array}{l}\text { - Keeping record on individual pupil is a } \\
\text { challenging task. }\end{array}$ & 30.124 & .000 & 2.79767 & 2.6148 & 2.9806 \\
\hline $\begin{array}{l}\text { - Establishing learning environment for } \\
\text { pupils for skill development is a } \\
\text { challenging task. }\end{array}$ & 31.372 & .000 & 2.86381 & 2.6840 & 3.0436 \\
\hline $\begin{array}{l}\text { Individualizing teaching and learning } \\
\text { activities in the classroom is a challenging } \\
\text { task }\end{array}$ & 31.707 & .000 & 3.05837 & 2.8684 & 3.2483 \\
\hline $\begin{array}{l}\text { Focusing pupils' attention to key issues } \\
\text { during science lessons is a challenging task. }\end{array}$ & 29.644 & .000 & 2.71984 & 2.5392 & 2.9005 \\
\hline $\begin{array}{l}\text { - Getting relevant teaching-learning } \\
\text { materials for teaching science is a } \\
\text { challenging task. }\end{array}$ & 38.499 & .000 & 3.55642 & 3.3745 & 3.7383 \\
\hline $\begin{array}{l}\text { - Getting materials to prepare teaching } \\
\text { learning materials for science lessons is } \\
\text { very challenging. }\end{array}$ & 49.474 & .000 & 3.77432 & 3.6241 & 3.9246 \\
\hline $\begin{array}{l}\text { Pupils do not show interest in science lesson } \\
\text { in my class. }\end{array}$ & 28.532 & .000 & 2.45136 & 2.2822 & 2.6206 \\
\hline $\begin{array}{l}\text { - It is difficult completing a scheme of work } \\
\text { prepared for science in a term }\end{array}$ & 31.657 & .000 & 2.85992 & 2.6820 & 3.0378 \\
\hline $\begin{array}{l}\text { - I use improvised TLMs for science lessons } \\
\text { than real TLMs. }\end{array}$ & 32.905 & .000 & 3.32685 & 3.1277 & 3.5260 \\
\hline $\begin{array}{l}\text { - Addressing pupils' misconceptions during } \\
\text { science lessons is very challenge. }\end{array}$ & 30.455 & .000 & 2.68093 & 2.5076 & 2.8543 \\
\hline $\begin{array}{l}\text { - Weekly lesson plan makes it difficult for } \\
\text { teachers to build on previous successes and } \\
\text { correct the weaknesses in subsequent } \\
\text { lessons. }\end{array}$ & 31.095 & .000 & 2.96887 & 2.7809 & 3.1569 \\
\hline
\end{tabular}

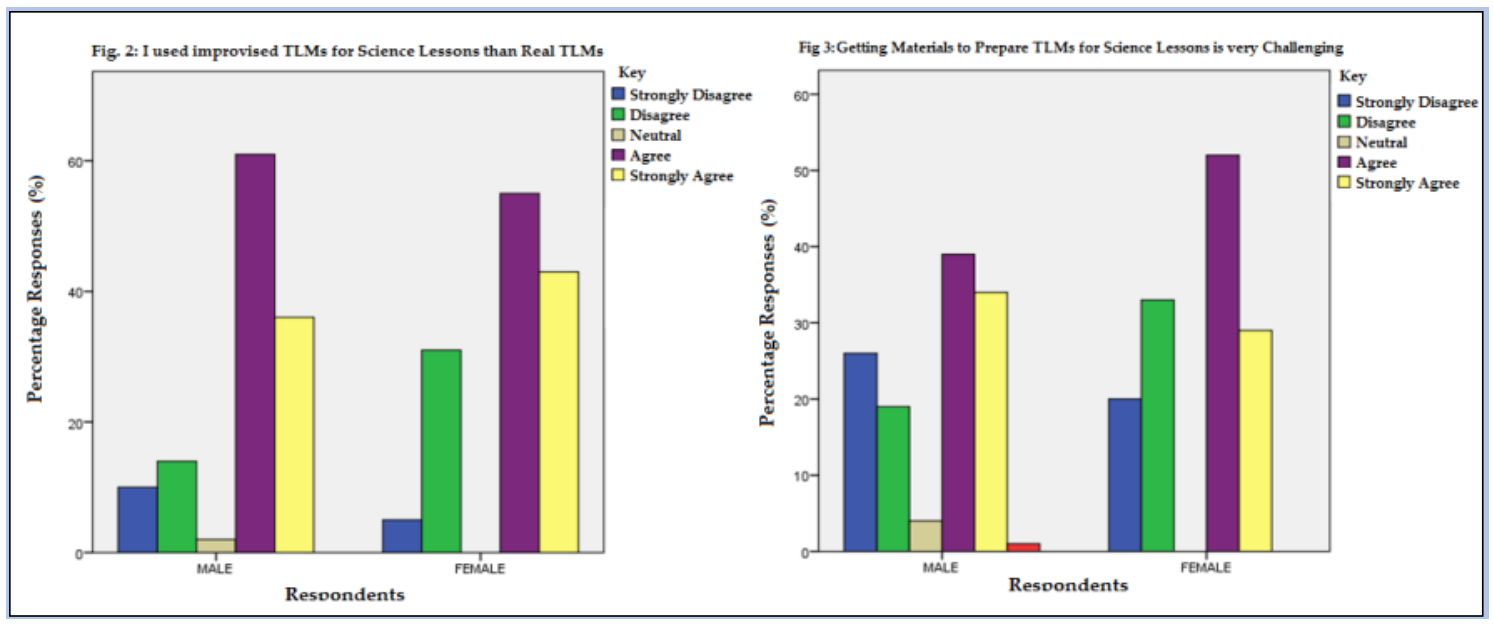

$[\chi=11.356, p<0.005]$

$[\chi=10.568, p<0.005]$ 
Table 5: T-Statistics Results Table of Teachers' Knowledge of Science-Based Global Best Practices

Knowledge of Science-Based Specific Practices

- Teachers need to be life-long learners

- Relating classroom lessons to real life situations is relevant in science teaching and learning.

- Not every science topic has relevant previous knowledge.

- Pupils understand science concepts better when I explain them using the local language

- Pupils' interest in science lessons can be stimulated through punishment.

- Not every science topics requires use of teaching learning materials.

- Weekly lesson plans do not encourage the use of reflective feedback in subsequent lessons.

- Remarks in science lessons cover only pupils' level of understanding and not teacher's methodology.

- During science lessons, the teacher must strictly follows what he/she has planned to teach.

- Ability to create opportunities for pupils to think critically and solve problems is an important characteristic of a science teacher.

- Introduction to every science lessons requires use of relevant previous knowledge.

- Teachers must share their lesson objective(s) with pupils any time they are about to teach.

- Pupils' misconceptions are relevant resources in science teaching and learning.

- In preparing science lesson plan, any one of the three main curriculum materials adequate information.

- Lesson introduction helps eliminate pupils' misconceptions in the previous knowledge.

- Teaching and learning is a collaborative work between the teacher and the learners.

[t- Statistics significant at $0.05(95 \%$ CI)].

The demographic profiles of teachers are summarized in Table 1 above. The number of teachers was 257. Among the teachers, there were slightly more female teachers $(52.1 \%)$ than male teachers $(47.9 \%)$. The age distribution of participants' shows that majority of them belonged to age group of 26.31 with mean age of 2.5875 and standards deviation of 1.1596 . Regarding the academic qualifications, more than half $(59.9 \%)$ of the teachers had teachers' diploma certificates, and the rest comprising 4 (1.6\%), 20 (7.8\%) and $3(1.2 \%)$ had Cert A-4 Year Certificates, Cert A 3-Year Certificates and master's degrees, respectively.

\begin{tabular}{|c|c|c|c|c|}
\hline \multicolumn{5}{|c|}{ One-Sample Test: $\mathrm{N}=\mathbf{2 5 7}, \mathrm{df}=\mathbf{5 6}$} \\
\hline \multirow[t]{2}{*}{$\mathbf{t}$} & \multirow[t]{2}{*}{$\begin{array}{c}p- \\
\text { value }\end{array}$} & \multirow[t]{2}{*}{$\begin{array}{c}\text { Mean } \\
\text { Difference }\end{array}$} & \multicolumn{2}{|c|}{$\begin{array}{l}\text { 95\% Confidence } \\
\text { Interval of the } \\
\text { Difference }\end{array}$} \\
\hline & & & Lower & Upper \\
\hline 78.459 & .000 & 4.36187 & 4.2524 & 4.4713 \\
\hline 42.370 & .000 & 3.74708 & 3.5729 & 3.9212 \\
\hline 29.639 & .000 & 2.52140 & 2.3539 & 2.6889 \\
\hline 35.571 & .000 & 3.33852 & 3.1537 & 3.5233 \\
\hline 27.828 & .000 & 2.04280 & 1.8982 & 2.1874 \\
\hline 26.938 & .000 & 2.05837 & 1.9079 & 2.2088 \\
\hline 29.316 & .000 & 2.54475 & 2.3738 & 2.7157 \\
\hline 29.387 & .000 & 2.61479 & 2.4396 & 2.7900 \\
\hline 28.980 & .000 & 2.59144 & 2.4153 & 2.7675 \\
\hline 40.203 & .000 & 3.63424 & 3.4562 & 3.8123 \\
\hline 41.819 & .000 & 3.61868 & 3.4483 & 3.7891 \\
\hline 42.834 & .000 & 3.63424 & 3.4672 & 3.8013 \\
\hline 35.902 & .000 & 3.26459 & 3.0855 & 3.4437 \\
\hline 34.435 & .000 & 3.05058 & 2.8761 & 3.2250 \\
\hline 32.245 & .000 & 3.01946 & 2.8351 & 3.2039 \\
\hline 43.387 & .000 & 3.85603 & 3.6810 & 4.0310 \\
\hline
\end{tabular}


Data presented in Table 2 above shows results from the descriptive statistics of teachers' knowledge of science-based global best practices. This data suggests that the majority of the teachers had good knowledge of science-based global best practices (mean knowledge ranged between 3.0-4.4 which is largely considered good).

The data in Table 3 suggested that the major challenges science teachers encounter whilst teaching science include difficulty in getting relevant teaching learning materials (mean $=3.556, \mathrm{SD}=1.480 ; \mathrm{t}=38.499, \mathrm{p}<0.05$ ); getting resources to prepare teaching learning materials for science lessons (mean $=3.774, \mathrm{SD}=1.223 ; \mathrm{t}=49.474$, $\mathrm{p}<0.05$ ) and over-reliance on use of improvised teaching learning materials (mean $=3.327, \mathrm{SD}=1.621 ; \mathrm{t}=$ $32.905, \mathrm{p}<0.05)$. Of these three challenges, getting materials to prepare teaching-learning aids (TLMs) scored the highest mean value of 3.774, suggesting that the greatest challenge science teachers' face in teaching science is lack of teaching learning resources. The test results showed that these factors are statistically significant.

The result highlighted in Figure 1 also indicates that the single most important topic science teachers found very difficult in teaching is basic electronics and more female teachers $(65 \%)$ than male teachers $(58 \%)$ found teaching of electronic concept more challenging. The data presented in Figures 2 and 3 also suggested that science teachers relied more on improvised TLMs than real TLMs and getting materials for preparing the improvised TLMs was a herculean task. Majority of the participants were in province of these findings.

Comparing the mean differences of teachers' knowledge of science-based global best practices, the data in Table 5 suggests that teachers being life-long learners scored the highest mean difference (mean difference $=$ $4.362 ; \mathrm{t}=78.459, \mathrm{p}<0.05)$ followed by teaching and learning is a collaborative work between the teacher and the learners (mean difference $=3.856 ; \mathrm{t}=43.387, \mathrm{p}<0.05$ ). Analysis of variance further confirmed statistically significant difference in mean squared of teachers' knowledge of science-based global best practices (mean square $=93.037, \mathrm{~F}(256)=42.285, \mathrm{p}<0.05)$.

\section{Discussion}

This study sought to investigate the teachers' knowledge of science-based global best practices and the challenges they face whilst teaching science at the basic school level. The discussion of the findings have been presented in terms of teachers' demographic characteristics; knowledge of science-based global best practices; and the challenges basic school science teachers face in teaching science.

\subsection{Teachers Demographic Characteristics}

This result suggests that females constitutes the majority of the teachers $(52.1 \%)$ and the male forming $47.9 \%$. Again, age distribution of teachers' shows that majority of them belonged to age group of 26.31 with mean age of 2.5875 and standards deviation of 1.1596. In terms of academic qualifications, more than half (59.9\%) of the participants had diploma certificates in teaching. According to Koh and Koh (1999); Gracia and Jenkins (2003) and Vickers et al. (2003), gender is an important factor affecting children's learning outcomes. By this, they mean that women act better than men and this issue strengthens theories about role of gender in academic performance. It is interesting to say that the findings of the present research are also consistent with these studies.

\subsection{Teachers Knowledge of Science-Based Global Best Practices}

The results of the study revealed that majority of the teachers have good knowledge of science-specific global best practices. Previous studies have demonstrated that the teachers knowledge base strongly influences all aspects of teaching like preparation, planning and decision making regarding the choice of content to be learnt (De Jong, Veal, \& Van Driel, 2002). Therefore, one can argue that one of the most important characteristics of being a good science teacher is having a very good knowledge of subject matter. However, research studies which have attempted to find a relationship between subject matter knowledge and good teaching (Abell, 2007; Childs \& Mc Nicholl, 2007; Hashweh, 1987; Kind, 2009) suggest that while a good background in subject matter knowledge is a pre-requisite for good teaching, it is not the only requirement. For example, exemplary science teachers, as argued by Shulman $(1986,1987)$ also need to develop pedagogical content knowledge which enables science teachers to blend "content and pedagogy into an understanding of how particular topics, problems, or issues are organised, represented, and adapted to the diverse interests and abilities of learners and presented for instruction" (Shulman, 1987, p. 8). Further studies revealed that having an in-depth knowledge of the subject matter helps teachers provide alternative explanations or use different approaches to help students understand complex scientific concepts.

\subsection{Challenges Basic School Science Teachers Face in Teaching Science}

The results of the indicated the major challenges science teachers encounter whilst teaching science included difficulty in getting relevant teaching learning materials; difficulty in getting materials to prepare teaching learning materials for science lessons and over-reliance on use of improvised teaching learning materials. Studies show that when learners interact with teaching learning materials (TLMs) they obtain first-hand information about the materials, acquire knowledge, concepts and principles together with the development of subject-based process 
skills. Samatowa (2011) demonstrated that direct experience provides an important role as a driving force for children's cognitive development.

The result also revealed that the single most important topic basic school science teachers find very difficult in teaching is 'basic electronics' and slightly more female teachers (65\%) than male teachers (58\%) found teaching of this concept more challenging. This is an indication that the basic electronics concept is not effectively handled at the initial teacher preparation stage, thus making pre-service teachers deficient in both content and pedagogical content knowledge of the concept.

The results further showed that the basic school science teachers relied more on improvised TLMs than real TLMs and even getting materials for preparing the improvised TLMs was a herculean task. Learning outcomes at school are the result of what happens in classrooms. One of such classroom situation that enhances classroom learning outcomes is availability of relevant teaching and learning resources. At the basic school level, the children are at the concrete operation developmental stage (7-11 years) and therefore needs concrete objects to operate and not verbally expressed hypotheses. Where teachers find it difficult in getting teaching and learning resources for effective classroom activities, they present their lessons without resources. In such situations learning becomes very difficult and the end result is low leaning outcomes. Providing quality science education at the basic school level, teachers must facilitate learning in the classroom. Learning materials and resources provide cognitive scaffold that facilitates the understanding and extension of knowledge (Salomon \& Perkins, 1998. According to Ghamdi and Salouli (2013), scarcity of teaching-learning resources are strong barriers that hinder effective classroom learning and skill development. To achieve quality science education as enshrined in goal 4 of the Sustainable Development Goals, there is an urgent need to ensure that schools are provided with relevant and adequate teaching learning resources.

\section{Conclusions}

The study investigated the teachers' knowledge of science-based global best practices and the challenges they face whilst teaching science at the basic school level. The results of the study showed that teachers had adequate knowledge of science-based global best practices. However, lack of teaching and learning resources and overreliance on improvised teaching and learning resources were perceived among the greater number of teachers as the most important drawback to effective teaching and learning of science in the district. Finally, the single most important concept science teachers found very difficult in teaching is 'basic electronics'. These findings provide a holistic understanding of the teachers' present knowledge of science-based best practices and the challenges they face whilst teaching science at the basic school level. These findings have important implications for Teacher Educators and for school administrators and might indicate the need for refresher courses and workshops for science teachers in the District.

\section{Recommendations}

Based on the findings of the study, the following are recommendations to enhance effective teaching and learning of science at the basic school level. First, there is urgent need for Ghana Education Service to support science teachers with relevant teaching leaning resources to help them provide conducive learning environment and learning opportunities that promote development of creativity and innovation, critical thinking and problemsolving skills among learners. Second, the Akuapem South Education District must organise refresher courses and workshops for science teachers to upgrade their knowledge on both contents and pedagogical content knowledge necessary for teaching and learning of basic electronic topics in the curriculum. Finally, the curriculum for preservice teacher preparation should include the teaching of basic electronic concepts.

\section{Acknowledgements}

The authors are grateful to the teachers and staff of Akuapem South District of the Eastern Region for their contribution to the success of this study.

\section{Conflict of Interest}

The authors declare no potential conflicts of interests.

\section{References}

Abell, S. (2007). Research on science teacher knowledge. In Abell, S. And Lederman, N. (eds.) Handbook of Research on Science Education, p. 1105-1149.

Abell, S. K. (2008). Twenty Years Later: Does pedagogical content knowledge remain a useful idea? International Journal of Science Education, 30 (10), 1405-1416.

Al Shammeri, A. (2013). Curriculum Implementation and Reform: Teachers' Views about Kuwait's New Science Curriculum. US-China Education Review, 3(3), 181-186.

Al Ghamdi, A.H., \& Al-Salouli, M. S. (2013). Saudi Elementary School Science Teachers' Beliefs: Teaching 
Science in the New Millennium. International Journal of Science \& Mathematics Education, 11(2), $501-525$.

Childs, A., \& McNicholl, J. (2007). Science teachers teaching outside of subject specialism: challenges, strategies adopted and implications for initial teacher education. Teacher Development, 11(1), 1-20.

Cronbach, L. J. (1951). Coefficient alpha and the internal structure of tests. Psychometrika, 16,297-334 (28,307 citations in Google Scholar as of 4/1/2016).

Daryanto. (2014). Pembelajaran Tematik Terpadu Terintegrasi (Kurikulum 2013). Yogyakarta: Gava Media.

Davidson, C. M. (2010). The Higher Education Sector in the Gulf: History, Pathologies, and Progress. Dubai: Gulf Research Center.

Davis, E.A., Petish, D., \& Smithey, J. (2007). Challenges new science teachers' face. Review of Educational Research, 76 (4), 607-651.

De Jong, O., Veal, W.R., \& Van Driel, J.H. (2002). Exploring Chemistry teachers' knowledge base. In Gilbert, J.K., de Jong, O., Justi. R., Treagust, D.F. \& Van Driel, J.H. (eds). Chemical Education: Towards Research Based Practice, p. 369- 390. Kluwer Academic Publishers: Netherlands.

Donaldson, G. (2010). Teaching Scotland's future: Report of a review of teacher education in Scotland.

Edinburgh: The Scottish Government Donaldson.

Gracia, L. and Jenkins, E. (2003). A quantitative exploration of student performance on an undergraduate accounting programme of study. Accounting Education, 12 (1), 15-32.

Hashweh, M, Z. (1987). Effects of Subject Matter Knowledge in the Teaching of Biology and Physics. Teaching and Teacher Education, 3 (2), 109-120.

Kind, V. (2009). A Conflict in your Head: An exploration of trainee science teachers' subject matter knowledge development and its impact on teacher self-confidence. International Journal of Science Education, 31 (11), 1529-1562.

Kind, V. \& Kind, P.M. (2011). Beginning to Teach Chemistry: How personal and academic characteristics of preservice science teachers compare with their understandings of basic chemical ideas. International Journal of Science Education, 33 (15), 2123- 2158.

Koh, M.Y. and Koh, H.C. (1999). The Determinants of performance in an accountancy degree course. Accounting Education: An International Journal, 8(1), 13-29.

Magnusson, S. K., \& Krajcik, J. J. \& Borko, H. (1999). Nature, sources and development of pedagogical content knowledge for science teaching.

Pedaste, M., Mäeots, M., Leijen, Ä. \& Sarapuu, S. (2012). Improving students' inquiry skills through reflection and self-regulation scaffolds. Technology, Instruction, Cognition and Learning, 9, 81-95

Salomon, G, \& Perkins, DN (1998). Chapter 1: individual and social aspects of learning. Review of Research in Education, 23(1), 1-24.

Samatowa, U. (2011). Pembelajaran IPA di Sekolah Dasar. Jakarta: PT Indeks.

Sengul, S.H., Cetin, G. \& Gur, H. (2008). The Primary School Science Teachers' Problems in Science Teaching. Journal of Turkish Science Education, 5(3), 82-88.

Shulman, L. S. (1986). Those who understand: Knowledge growth in teaching. Educational Researcher, 15 (2), $4-$ 14. Shulman, L. S. (1987). Knowledge and Teaching: Foundations of the New Reform. Harvard Educational Review, 57 (1), 1-22.

Vickers, M., Lamb, S. and Hinkley, J. (2003). Student workers in high school and beyond: the effects of part-time employment on participation in education, training and work. Longitudinal Surveys of Australian Youth: a research program by the Australian Council for Educational Research (ACER) and the Commonwealth Department of Education, Science and Training (DEST). Camberwell Victoria, Australia. 